\title{
Specific growth rate of sulfate reducing bacteria in the presence of manganese and cadmium
}

\author{
Sílvia N. Medírcio, Versiane A. Leão*, Mônica C. Teixeira \\ Núcleo de Valorização de Materiais Minerais, Universidade Federal de Ouro Preto, Praça Tiradentes, \\ 20, Centro, Ouro Preto, MG 35400-000, Brazil
}

Received 31 August 2006; received in revised form 22 September 2006; accepted 25 September 2006

Available online 29 September 2006

\begin{abstract}
The development of technologies based on the use of sulfate-reducing bacteria (SRB) to treat sulfate contaminated wastewaters has produced a cost-effective route to precipitate metals. In this work the effects of cadmium and manganese in the SRB growth rates were assessed. It was observed that duplication time is $50 \mathrm{~h}$ in the presence of cadmium and $6 \mathrm{~h}$ in the presence of manganese, thus showing that the SRB growth rate was more affected by the presence of cadmium. A low sulfate reduction (maximum 25\%) occurred which was sufficient for metal precipitation. The results are discussed considering their implications for metal precipitation in acid mining drainage.
\end{abstract}

(C) 2006 Published by Elsevier B.V.

Keywords: Specific growth rate; Sulfate-reducing bacteria; Cadmium; Manganese

\section{Introduction}

Currently, acid mine drainage (AMD) is considered by the mining industry as its principal environmental issue. AMD formation is a bacterially mediated process, where mineral sulfides are oxidized, producing sulfuric acid. The main concern is iron sulfides (pyrite and pyrrhotite). Pyrite, for instance, oxidizes directly to sulfate, producing net acidity [1]. Iron-oxidizing bacteria, such as those of the genera Acidithiobacillus and Leptospirillum, catalyze $\mathrm{Fe}$ (II) oxidation, increasing the rate as high as five orders of magnitude [2].

Chemical methods can be applied in order to treat AMD. Lime $(\mathrm{CaO})$ or $\mathrm{NaOH}$ are used to increase the $\mathrm{pH}$ of AMD. These chemicals may be expensive and the produced sludge, usually highly contaminated with heavy metals, must be dewatered and disposed of in a landfill. However, metals can be remobilized if the landfill site is leached by surface or groundwater [3]. Another problem faced by AMD treatment plants is high sulfate content of the water [4]. The issue of sulfate removal is being addressed by the use of a biological process involving sulfate-reducing bacteria (SRB). Currently biological sulfate reduction is considered

\footnotetext{
* Corresponding author. Tel.: +55 313559 1102; fax: +55 3135591561

E-mail address: versiane@ demet.em.ufop.br (V.A. Leão).
}

one of the most promising technologies that can be applied for metals precipitation, as well as sulfate removal [3,5].

Biological sulfate reduction is a natural process. SRB utilize sulfate, under anaerobic conditions, as an electron acceptor during the oxidation of organic substrates, therefore generating sulfide and bicarbonate ions. While the latter contributes to increase the $\mathrm{pH}$, hydrogen sulfide precipitates dissolved metals. The alkalinity produced during sulfate reduction can also promote metals precipitation as carbonates, thus removing some metals that are not usually removed at the typical $\mathrm{pH}$ conditions produced during AMD chemical treatment.

The effects of manganese and cadmium on the growth rate of a SRB strain were studied. Synthetic solutions containing each metal were examined simulating the effluent from a chemical AMD treatment plant. After precipitation with lime, cadmium and manganese remained as the main heavy metals in the effluent. That cadmium has a detrimental effect on bacterial growth in comparison to manganese was observed in the present work.

\section{Experimental}

The SRB strain used in the present work was a coccus-like and Gram-positive isolate. A previous study showed that the strain grows with acetate and other carbon sources, as well as in the presence of oxygen due to the presence of the catalase 
enzyme [6]. This strain is currently being characterized using molecular biology techniques.

Bacterial growth and metal precipitation were studied with batch experiments. The composition of the growth medium was: $\mathrm{Na}_{2} \mathrm{SO}_{4}, 5.74 \mathrm{~g} / \mathrm{L} ; \mathrm{CH}_{3} \mathrm{COONa}, 5.50 \mathrm{~g} / \mathrm{L} ; \mathrm{NaNO}_{3}, 1.0 \mathrm{~g} / \mathrm{L}$; $\mathrm{KH}_{2} \mathrm{PO}_{4}, 1 \mathrm{~g} / \mathrm{L}$. The solution $\mathrm{pH}$ was adjusted to 6.0 with $\mathrm{H}_{2} \mathrm{SO}_{4}$. Manganese and cadmium solutions were prepared from $\mathrm{MnSO}_{4} \cdot \mathrm{H}_{2} \mathrm{O}$ and $\mathrm{CdSO}_{4} \cdot 8 \mathrm{H}_{2} \mathrm{O}$, respectively. Both solutions and the growth medium were sterilized separately $\left(120^{\circ} \mathrm{C}\right.$, $20 \mathrm{~min}, 1.5 \mathrm{~atm}$ ) and mixed, after cooling, to produce the working solutions. During the experiments, the individual manganese and cadmium solutions contained, respectively, 19.9 and $19.5 \mathrm{mg} / \mathrm{L}$. All chemicals were provided by Synth.

Metal precipitation was carried out in $100 \mathrm{~mL}$ dark glass bottles containing $20 \%$ washed sand $(96 \%$ below $420 \mu \mathrm{m})$, at $34{ }^{\circ} \mathrm{C}$. The experiments were carried out in triplicate and each bottle was inoculated with $200 \mu \mathrm{L}$ of a solution containing $4.0 \times 10^{7}$ cells $/ \mathrm{mL}$. A fourth bottle with no inoculum was used as a negative control. The bottles had $98 \%$ of their volume filled with solution to remove air so that anaerobic conditions were created.

Sulfate was measured by the turbidimetric method in the presence of barium chloride $\left(\mathrm{BaCl}_{2}\right)$ [7]. Metal concentrations were determined using an AAnalyst 100 (Perkin Elmer) atomic absorption spectrophotometer. The $\mathrm{pH}$ values were measured using a HI9622 meter (Hanna Instruments). Cell counts were assessed by direct counting in a Neubauer chamber, using a phase contrast microscope (Leica).

The specific growth rate $(\mu)$ was calculated by plotting the logarithm of bacterial population as a function of time (Eq. (1)). A straight line is produced whose slope is the specific growth rate. Based on the specific growth rate, the duplication time $(G)$ was estimated by Eq. (2) [8]:

$\ln (X)=\mu t-B$

where $X$ accounts for bacterial population (cells/mL), $A$ and $B$ are constants and $t$ for time (h).

$G=\frac{\ln 2}{\mu}$

\section{Results and discussion}

Bacterial growth and metal concentrations in solution, as a function of time, are depicted in Figs. 1 and 2. These figures show that, at the experimental conditions of the present work, the SRB strain is less sensitive to the presence of manganese ions compared to cadmium ions. Bacterial growth rate and bacterial cell counts are higher in the presence of the first compared to the latter. During the growth experiments in the presence of cadmium, the maximum bacterial count obtained is one tenth of the value achieved in the presence of manganese. Furthermore, the effect of cadmium may also be observed during the lag phase. The exponential growth phase lasted $24 \mathrm{~h}$ in the presence of manganese and $96 \mathrm{~h}$ in the experiments with cadmium. All this evidence suggests that cadmium toxicity to this bacterium is higher as compared to manganese [9-11]. The effects of cadmium on microorganism growth are usually related to deleterious effects on protein synthesis [12]. Resistance to cadmium involves metal-binding proteins mediated by metallothionein-encoding genes [11]. Figs. 1 and 2 also show that as soon as the lag phase ends (4th day) and the exponential growth phase starts, the increase in the bacterial population coincides with a sharp decrease in metal concentrations in both systems.
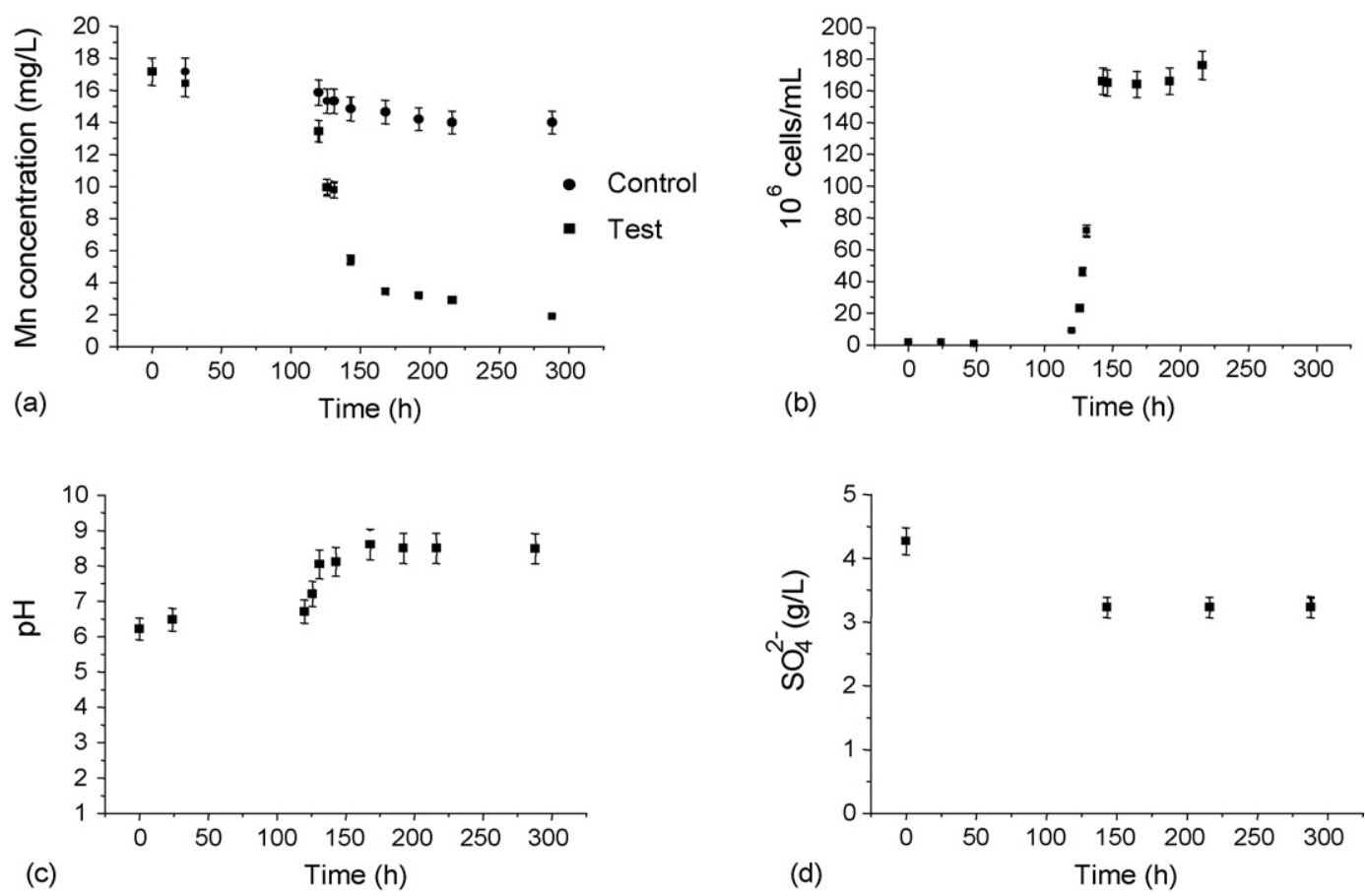

Fig. 1. Metal precipitation (a), cell counts (b), pH variation (c), and sulfate reduction (d) in batch bottles in the presence of manganese. 

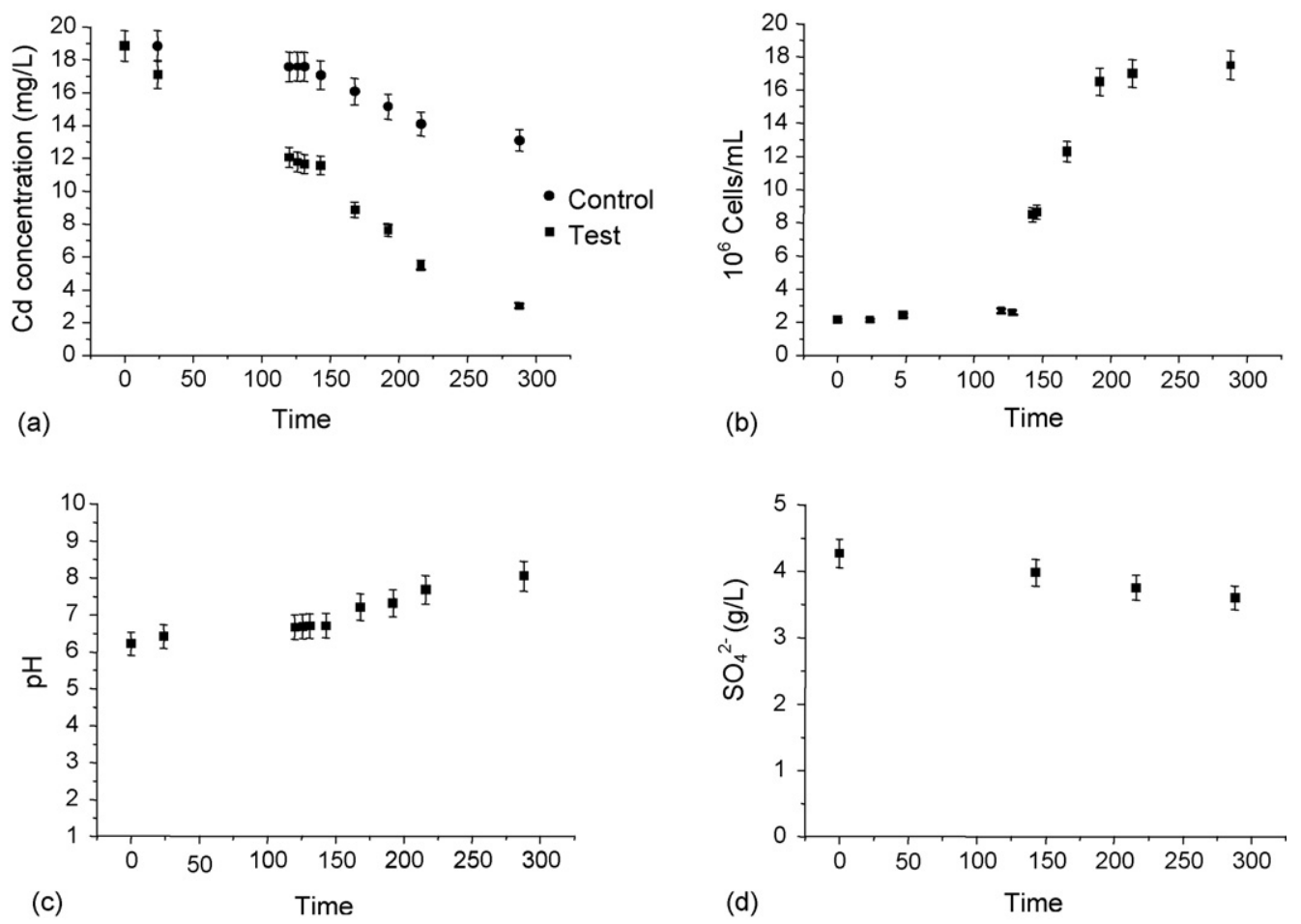

Fig. 2. Metal precipitation (a), cell counts (b), pH variation (c), and sulfate reduction (d) in batch bottles in the presence of cadmium.

Nevertheless, cadmium concentration drops slower in comparison to that of manganese. This is because sulfide and $\mathrm{HCO}_{3}{ }^{-}$ production depends on the biological sulfate reduction that, in turn, is slower in the presence of cadmium. The overall result is a slower bacterial growth in the presence of cadmium and a faster increase in bacterial population for manganese-containing systems. These results, as depicted in Figs. 1 and 2, may be treated according to Eq. (1) so that Eqs. (3) and (4) can be achieved:

$\ln (X)=0.123 t-12.21 \quad$ (in the presence of manganese)

$\ln (X)=0.014 t-0.148 \quad$ (in the presence of cadmium)

Based on Eqs. (3) and (4), the specific growth rate $(\mu)$ in the presence of cadmium and manganese were 0.014 and $0.123 \mathrm{~h}^{-1}$, respectively. Furthermore, the SRB duplication times, determined by Eq. (2), were 6 and $50 \mathrm{~h}$, respectively, in the presence of manganese and cadmium. These results reflect the detrimental effect of cadmium on the growth of SRB. Although no adaptation of SRB to cadmium or manganese was carried out, the longer growth time required by SRB in the presence of cadmium would have important implications when the metal is removed in a reactor. Since biomass residence time must be higher than the duplication time, larger reactors are needed to biologically precipitate cadmium, as compared to manganese. Alternatively, the sulfate reduction step may be separated from cadmium precipitation [13].

The batch experiments showed 90\% manganese and $85 \%$ cadmium precipitation, after 13 days. Either sulfide or bicarbonate ions can precipitate both metals. Whether or not a metal carbonate or sulfide will be formed is defined by the relative stabilities of the metallic precipitates of both elements. Ginter and Grobicki [10], studying manganese precipitation in a UASB reactor noticed that the absence of sulfate hindered manganese precipitation. In this type of reactor, manganese would also be eliminated by sorption on the suspended sludge, although this process did not provide efficient manganese removal (only $7.2 \%$ ). Manganese removal was increased to $40 \%$ in the presence of $88.4 \mathrm{mg} / \mathrm{L}$ sulfate. It can be implied that alkalinity, produced during sulfate reduction, accounted for manganese precipitation as $\mathrm{MnCO}_{3}$. In another series of experiments, the authors added $50 \mathrm{mg} / \mathrm{L}$ cadmium to a sulfate solution and observed $56 \%$ manganese precipitation. This was attributed to the coprecipitation of manganese with cadmium [10]. Cadmium was efficiently removed $(99.9 \%)$ in a lactate-fed fluidized-bed reactor, although the nature of the precipitate was not determined [14].

Comparing $\mathrm{pH}$ evolution with bacterial growth, it can be seen that the relation between $\mathrm{pH}$ increase and bacterial growth is straightforward. Figs. 1 and 2 show that bacterial population (Figs. $1 \mathrm{~b}$ and $2 \mathrm{~b}$ ) and $\mathrm{pH}$ values (Figs. $1 \mathrm{c}$ and $2 \mathrm{c}$ ) present similar behaviors, suggesting that sulfate reduction accounts for $\mathrm{pH}$ increase. As SRB reduce sulfate and oxidize acetate, bicarbonate ions are generated and the water system is buffered at $\mathrm{pH} 8.3$ [15].

An analysis of sulfate concentrations can be carried out by observing the Figs. 1d and 2d. Sulfate content was reduced as bacterial cell counts increased. Although manganese inhibition of bacterial sulfate reduction [16] is suggested, sulfate content was reduced by $26 \%$ as compared with only $16 \%$ in the presence of cadmium. These results are consistent with the work of Tabak 
and Govind [17] that showed that sulfate reduction matched bacterial growth, leveling out after the exponential phase ended. Likewise, Christensen [5], studying sulfate reduction from AMD, observed that a sulfate consumption ranging from 614 to $893 \mathrm{mg} / \mathrm{L}$ was achieved, which represented $19-27 \%$ sulfate removal from its initial value $(3306 \mathrm{mg} / \mathrm{L})$. These values are also consistent with the results of the present work.

At least two different applications can be foreseen regarding the use of SRB technology in the mining industry. Firstly, SRB could be applied to reduce sulfate in effluents as well as process waters. Sulfate reduction is considered slow as compared to its chemical precipitation and concerns appear when high sulfate loads (which are very common in AMD) need to be treated. High levels of sulfate reduction in AMD would require very large reactors, which in turn, would challenge the feasibility of the technology. In this regard, it sounds more realistic to associate biological sulfate reduction with a chemical step that would be performed before sulfate reduction by SRB. Lime addition would, for example, decrease sulfate contents in streams and the process involving SRB could be applied as a polishing step afterwards. Secondly, in those conditions where sulfate reduction is not the primary target, but instead, metal precipitation is the objective, the use of the biologically produced sulfide and alkalinity in order to promote metal precipitation is very promising. This approach has already been applied, as a polishing step during the treatment of an arsenic contaminated effluent [18]. Nevertheless, whether sulfate reduction or metal precipitation is sought, the successful application of SRB will require addressing the acidic conditions found in AMD. This is because SRB do not grow at the typical $\mathrm{pH}$ observed in AMD. To overcome this, it would be necessary: (i) to select SRB strains capable of thriving in at least mildly acidic streams as, for example, those isolated in naturally acidified waters; (ii) the acidotolerante SRB strains should also be able to reduce sulfate at a reasonable rate [19] in those cases where sulfate reduction is the main concern; (iii) an engineered approach would be used to prevent SRB from encountering low $\mathrm{pH}$ waters during AMD treatment [20].

\section{Conclusions}

In the present work, SRB precipitated both cadmium and manganese. Cadmium, being more toxic, reduced the bacterial growth rate, i.e., the duplication time was $6 \mathrm{~h}$ in the presence of manganese and $50 \mathrm{~h}$ in the presence of cadmium. Thus, provided concentrations are low, heavy metals can be efficiently removed. A polishing step for the treatment of heavy metal-containing waters can be carried out with SRB since they can precipitate metals and increase $\mathrm{pH}$ even when partial sulfate reduction is achieved.

\section{Acknowledgements}

The financial support for this work from "FINANCIADORA DE ESTUDOS E PROJETOS - FINEP”, is gratefully appreciated. The "Universidade Federal de ouro Preto" scholarship to S.N. Medírcio is also acknowledged. Authors are also grateful to reviewers whose comments contributed to improve the quality of this paper.

\section{References}

[1] A. Schippers, W. Sand, Bacterial leaching of metal sulfides proceeds by two indirect mechanisms via thiosulfate or via polysulfides and sulfur, Appl. Environ. Microbiol. 65 (1) (1999) 319-321.

[2] D.T. Lacey, F. Lawson, Kinetics of the liquid-phase oxidation of acid ferrous sulfate by the bacterium Thiobacillus ferrooxidans, Biotechnol. Bioeng. 12 (1970) 29-50.

[3] P. Elliott, S. Ragusa, D. Catcheside, Growth of sulfate-reducing bacteria under acidic conditions in an upflow anaerobic bioreactor as treatment system for acid mine drainage, Water Res. 32 (12) (1998) 3274-3730.

[4] J.R. Lloyd, D.A. Klessa, D.L. Parry, P. Buck, N.L. Brown, Simulation of microbial sulphate reduction in a constructed wetland: microbiological and geochemical analysis, Water Res. 38 (2004) 1822-1830.

[5] B. Christensen, M. Laake, T. Lien, Treatment of acid mine water by sulfatereducing bacteria: results from a bench scale experiment, Water Res. 30 (7) (1996) 1617-1624.

[6] S.N. Medírcio, Redução do teor de sulfato em águas pela utilização de bactérias redutoras de sulfato (Sulfate Removal from Wastewaters with Sulfate Reducing Bacteria). ouro Preto, Universidade Federal de ouro Preto, MG, Brazil, 2004, p. 78 (In Portuguese with abstract in English).

[7] L.S. Clesceri, A.E. Greenberg, A.D. Eaton, Standard Methods for the Examination of Water and Wastewater, 20th ed., APHA, AWWA, WEF, Baltimore, MD, 1998.

[8] M. Vossoughi, M. Shakeri, I. Alemzadeh, Performance of anaerbic baffled reactor treating synthetic wastewater influenced by decreasing $\mathrm{COD} / \mathrm{SO}_{4}$ ratios, Chem. Eng. Process. 42 (2003) 811-816.

[9] C. Garcia, B.A. Moreno, A. Ballester, M.L. Blázques, F. González, Bioremediation of an industrial acid mine water by metal tolerant suphatereducing bacteria, Miner. Eng. 14 (9) (2001) 997-1008.

[10] M.O. Ginter, A.M. Grobicki, Manganese removal mechanism in a stirred UASB reactor, Water Res. 31 (6) (1997) 1261-1268.

[11] N. Naz, H.K. Young, N. Ahmed, G.M. Gadd, Cadmium accumulation and DNA homology with metal resistance genes in sulfate-reducing bacteria, Appl. Environ. Microbiol. 71 (2005) 4610-4618.

[12] J.T. Trevors, G.W. Stratton, G.M. Gadd, Cadmium transport, resistance, and toxicity in bacteria, algae, and fungi, Can. J. Microbiol. 32 (6) (1986) 447-464.

[13] H.H. Tabak, R. Govind, Advances in biotreatment of acid mine drainage and biorecovery of metals: 1 . Metal precipitation for recovery and recycle, Biodegradation 14 (2003) 423-436.

[14] X. Ma, Y. Hua, $\mathrm{Cd}^{2+}$ removal from wastewater by sulfate reducing bacteria with an anaerobic fluidized be reactor, J. Environ. Sci. 9 (1997) 366-371.

[15] S.E. Manahan, Environmental Chemistry, 7th ed., Lewis, New York, 2000, p. 898.

[16] K. Yoo, K.N.H. Sasaki, M. Tsunekawa, T. Hirajima, The effect of $\mathrm{Mn}^{2+}$ concentration on $\mathrm{Mn}$ removal by a sulfate reducing bacteria bioreactor, Mater. Trans. 45 (2004) 2429-2434.

[17] H.H. Tabak, R. Govind, Advances in biotreatment of acid mine drainage and biorecovery of metals: 2 Membrane bioreactor system for sulfate reduction, Biodegradation 14 (2003) 437-452.

[18] T. Maniatis, P. Pickett, Biological removal of arsenic from tailings pond water at a Canadian mine, in: R.G. Reddy, V. Ramachandran (Eds.), Arsenic Metallurgy, The Minerals, Metals and Materials Society (TMS), San Francisco, CA, 2005, pp. 209-214.

[19] D.B. Johnson, A.M. Sen, S. Kimura, O.F. Rowe, K.B. Hallberg, Novel biosulfidogenic system for selective recovery of metals from acidic leach liquors and waste streams, Miner. Process. Extract. Metall. (Trans. Inst. Min. Metall. Sect. C). 115 (2006) 19-24.

[20] A.H. Kaksonen, J.J. Plumb, W.J. Robertson, M. Riekkola-Vanhanen, P.D. Franzmann, J.A. Puhakka, The performance, kinetics and microbiology of sulfidogenic fluidized-bed treatment of acidic metal- and sulfate-containing wastewater, Hydrometallurgy 83 (2006) 204-213. 